Apidologie, 1978, 9 (1), 33-40.

\title{
CHEMICAL COMPOSITION AND NUTRITIVE VALUE OF BEE-COLLECTED AND BEE-STORED POLLEN
}

\author{
Elton W. HERBERT, Jr. and H. SHIMANUKI \\ Bioenvironmental Bee Laboratory, Plant Protection Institute, \\ ARS, USDA \\ Beltsville, $M D 20705$
}

\begin{abstract}
SUMMARY
When fresh pollen and bee-stored pollen extracted from brood combs of free-flying colonies were offered to caged colonies of bees, there appeared to be no difference in nutritive value judged by the number of bees reared to the sealed stage.

Bee bread and pollen from seven locations were analyzed for "moisture, protein, reducing and nonreducing sugars, lipids, sulfated ash, starch, $p \mathrm{H}$, pectins and crude fiber. The levels of protein, moisture, and lipids differed little between pollen and bee bread. However, there was no detectable starch in any of the samples of bee bread; and starch was present in all seven samples of pollen (mean value of $1.77 \%$ ). In addition, bee bread contained higher levels of reducing sugar and crude fiber than pollen but lower levels of ash. The ash of all pollen samples ranged between 2.4 and $3.4 \%$ of the dry weight. The $p \mathrm{H}$ of bee bread averaged 4.1 compared with 4.8 for pollen. The percentage of undetermined matter in pollen and bee bread averaged less than $10 \%$ of the dry weight.
\end{abstract}

\section{INTRODUCTION}

Pollen substitutes formulated and tested at the Beltsville Bioenvironmental Bee Laboratory have been based on the levels of essential nutrients found in pollen, the predominant source of proteins, lipids, minerals, and vitamins in the diet of the honey bee, Apis mellifera $L$. However, the chemical composition of pollen varies with plant species, environment during pollen development, age of plant when pollen developed, nutrient status of the plant, methods of pollen extraction, and storage. Also this large variability in chemical composition is associated with an equally large variability in food value for the bee. For example, pollen of different plants do not have the same physiological effects (Maurizio, 1954, Todd and Bretherick, 1942, Lunden, 1954, 
Vivino and Palmer, 1944, Louveaux, 1963, Hugel, 1962); and nutritive value was not entirely correlated with protein quantity (TODD and BRETHERICK, 1942).

Bees do not consume pollen as collected by foragers. The pollen pellets are stored in cells; and honey, nectar, or glandular secretions are added to the mass of stored pollen. Pollen stored in this way undergoes a lactic acid fermentation and becomes what is called " bee bread". Stored pollen generally has a specific bacterial flora associated with it (Egorova, 1971, PAIN and MAUgenet, 1966); and PAIN and MAugenet (1966) found three microbial genera in bee bread: Pseudomonas, Lactobacillus, and Saccharomyces. This suggests that microorganisms are probably involved in the storage of pollen.

Bee bread stored in combs therefore differs from fresh bee-collected pollen, but the fermentation may be responsible for increased stabilization of the product or may lead to chemical changes that increase digestibility and nutritive value for the bee. Beutler and Opfinger (1949) found that bees lived longer on pollen removed from combs than from pollen traps.

We therefore compared the chemical properties of bee bread and pollen and also fed these materials to caged colonies of newly emerged bees to determine the brood rearing capability of each. A greater nutritive value of bee bread would suggest that our diets should be based on the chemical composition of bee bread, not of pollen.

\section{MATERIALS AND METHODS}

\section{Bees}

Bee-collected pollen obtained from pollen traps and stored pollen (bee bread) extracted from brood combs of free-flying colonies were offered to test colonies established in small queen-mating nucleus colonies $(23 \times 19 \times 27 \mathrm{~cm})$ located at Beltsville, Maryland. Each nucleus consisted of a mated queen, $400 \mathrm{~g}$ of newly emerged bees, and five drawn combs $(2.5 \times 16 \times 23 \mathrm{~cm})$ free of any honey or pollen. As soon as the nuclei were established, the bees were offered the bee bread or pollen diets by inverting petri dish lids $(100 \times 15 \mathrm{~mm})$ containing $50 \mathrm{~g}$ of diet over the brood combs. Then each nucleus was placed in a $2 \times 2 \times 2 \mathrm{~m}$ screen flight cage, and the bees were supplied with a $50 \%(\mathrm{w} / \mathrm{v})$ sucrose solution that was replenished twice a week when the diets were changed. After the first sealed brood appeared, the number of sealed cells was estimated once a week by using a wire grid of $6.25 \mathrm{~cm}^{2}$ divisions.

\section{Chemical A nalysis}

Bee-collected pollen and stored pollen obtained from seven different geographic locations in the U.S. were analyzed as follows:

The percent moisture in pollen and bee bread was determined by placing $5 \mathrm{~g}$ of each sample in a hotair oven at $100^{\circ} \mathrm{C}$ for $24 \mathrm{hr}$. After the samples were removed from the oven, they were allowed to reach room temperature and then weighed. The difference between dry weight and the initial weight was used to calculate percent moisture.

Total nitrogen content was determined by the AOAC Micro-Kjeldahl method (Association of Official Agricultural Chemists, 1960).

Total reducing and nonreducing sugars were determined by modifying AOAC method No. 13.028 for sugars in cereal foods. The quantity of reducing sugar was calculated as maltose for the Maltose-Sucrose 
Conversion Table (No. 13.030). The nonreducing sugar was reduced after hydrolysis and calculated as sucrose by using the same table.

The percent of crude lipids in each sample was determined by using a chloroform-methanol extraction. The chloroform layer was collected and washed three times with $100 \mathrm{ml}$ of a $0.1 \% \mathrm{NaCl}$ solution. The sample was dried, and the weight difference was used to calculate percentage crude lipid.

Sulfated ash in samples was determined according to AOAC Method No. 29.014.

The percentage starch in the samples was compared with a standard curve derived by taking measurements of a series of test tubes containing from $10 \mathrm{mg}$ to $100 \mathrm{mg}$ of soluble starch suspended in $20 \mathrm{ml}$ of distilled water to which $2 \mathrm{ml}$ of $\mathrm{KI}$ solution were added. The percentage transmittance was measured in a Bausch and Lomb Spectronic 20 at $450 \mathrm{~nm}$ and used to plot the standard curve.

The percentage of crude fiber and pectins in the pollen and bee bread sample was determined according to LEES (1971).

\section{RESULTS AND DISCUSSION}

There was no difference in the nutritive value of bee bread and pollen when based on the number of bees reared to the sealed stage. Bees fed either the pollen or the bee bread patties reared $7,195.50 \pm 243.75 \mathrm{~cm}^{2}$ and $7,046.00 \pm 152.93 \mathrm{~cm}^{2}$ larvae, respectively, to the capped stage. However, bees fed pollen did not initiate brood rearing immediately after they were offered the diet, probably because the bees were all newly emerged. Consumption of the diet was poor for the first 4 to 5 days. Several authors have observed that newly emerged bees do not feed on pollen immediately after they emerge, and this may account for the retarded brood rearing. HAYDAK (1933) found that most newly emerged bees only start to eat pollen between 12 to $18 \mathrm{hr}$ after emergence. HAGEDORN and McLler (1967) stated that newly emerged bees consume small amounts of pollen for the first $40 \mathrm{hr}$; thereafter, the rate of pollen consumption increases greatly. However, by the time the bees were $42 \mathrm{hr}$ old, $90 \%$ had consumed some pollen. In contrast, the first sealed cells in nuclei that were fed bee bread were observed 12 days after the queens were released. The levels of brood rearing remained relatively constant throughout the test period.

The chemical components of bee collected pollen and bee bread are summarized in Table 1 and 2 respectively. Values are expressed on a dry-weight basis. The last column represents the mean value for all seven locations. Most ranges were fairly uniform. Moisture, for example, ranged from $21.7 \%$ in the Wyoming sample to a high of $27.0 \%$ in the California sample; reducing sugars ranged from $12.6 \%$ to $30.2 \%$ (average $20.71 \%$ ), and nonreducing sugars ranged from 1.0 to $2.5 \%$. Our results were therefore similar to those of TODD and BRETHERICK (1942) who analyzed and found that the content of crude protein ranged from 7.02 to $29.87 \%$.

The values for starch, lipids, and sulfated ash obtained from all pollen samples were remarkably similar; starch was present in all seven samples (mean value of $1.77 \%$ ). The total percent of crude lipids ranged from $4.03 \%$ (Arizona) to $5.48 \%$ (Maryland), and the ash content ranged from 2.4 to $3.5 \%$ (mean of $3.17 \%$ ). 
TABLE 1. - Chemical analyses of bee-collected pollen (a) from seven locations (b)

\begin{tabular}{|c|c|c|c|c|c|c|c|c|}
\hline Test & Md. & N.-J. & Wisc. & Wyo. & Ariz. & La. & Cal. & Avg. \\
\hline 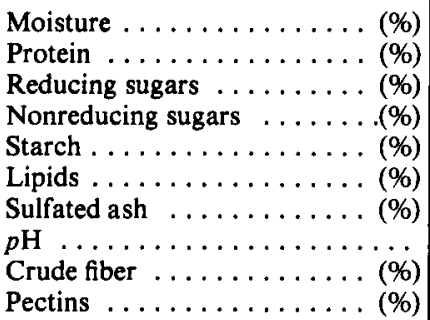 & $\begin{array}{r}24.0 \\
21.9 \\
15.9 \\
1.0 \\
2.9 \\
5.5 \\
3.2 \\
4.4 \\
7.2 \\
1.9\end{array}$ & $\begin{array}{r}23.1 \\
21.3 \\
21.8 \\
2.4 \\
2.2 \\
5.1 \\
2.4 \\
4.1 \\
8.4 \\
1.3\end{array}$ & $\begin{array}{r}26.6 \\
29.3 \\
21.3 \\
2.4 \\
2.9 \\
4.2 \\
3.4 \\
4.5 \\
4.2 \\
0.9\end{array}$ & $\begin{array}{r}21.7 \\
22.1 \\
30.2 \\
2.5 \\
0.8 \\
5.3 \\
3.4 \\
5.9 \\
7.4 \\
1.0\end{array}$ & $\begin{array}{r}22.6 \\
21.0 \\
20.7 \\
2.4 \\
0.9 \\
4.0 \\
3.5 \\
5.8 \\
11.4 \\
0.9\end{array}$ & $\begin{array}{r}25.2 \\
27.1 \\
22.5 \\
2.4 \\
1.0 \\
4.9 \\
2.9 \\
4.6 \\
7.9 \\
0.4\end{array}$ & $\begin{array}{r}27.0 \\
25.9 \\
12.6 \\
1.9 \\
1.8 \\
5.2 \\
3.5 \\
4.4 \\
\text { (c) } \\
\text { (c) }\end{array}$ & $\begin{array}{c}24.31 \\
24.1 \\
20.7 \\
2.1 \\
1.8 \\
4.9 \\
3.2 \\
4.8 \\
7.7 \\
1.6\end{array}$ \\
\hline
\end{tabular}

(a) Determinations on a dry weight basis.

(b) Average of three replications.

(c) Insufficient sample.

TABLE 2. - Chemical analyses of bee-stored pollen (a) from seven locations (b)

\begin{tabular}{|c|c|c|c|c|c|c|c|c|}
\hline Test & Md. & N.-J. & Wisc. & Wyo. & Ariz. & La. & Cal. & Avg. \\
\hline$\ldots \ldots \ldots \ldots(\%)$ & 28.0 & 23.8 & 21.3 & 18.8 & 21.5 & 27.8 & 25.4 & 23.8 \\
\hline Protein . & 21.1 & 23.1 & 26.5 & 25.8 & 22.8 & 19.3 & 24.5 & 23.3 \\
\hline Reducing sugars $\ldots$ & 28.2 & 23.7 & 21.8 & 37.3 & 34.7 & 35.3 & 14.0 & 27.9 \\
\hline Nonreducing sugars & 1.9 & 1.5 & 1.0 & 5.7 & 2.9 & 2.9 & 1.5 & 2.5 \\
\hline $\operatorname{Starch} \ldots \ldots \ldots \ldots \ldots \ldots$ (\%) & 0.0 & 0.0 & 0.0 & 0.0 & 0.0 & 0.0 & 0.0 & 0 \\
\hline Lipids $\ldots \ldots \ldots \ldots \ldots \ldots \ldots$ (\%) & 3.9 & 4.7 & 4.8 & 5.8 & 6.7 & 6.1 & 5.6 & 5 \\
\hline Ash $\ldots \ldots \ldots \ldots \ldots \ldots$ (\%) & 3.0 & 2.1 & 3.2 & 2.5 & 3.1 & 2.6 & 2.9 & 2 \\
\hline$p \mathrm{H} \ldots \ldots$ & 4.3 & 4.1 & 3.9 & 3.8 & 4.2 & 4.2 & 4.0 & 4. \\
\hline Crude fiber $\ldots \ldots \ldots \ldots \ldots$ (\%) & 7.1 & 6.6 & 18.5 & 9.1 & 9.3 & 5.8 & 17.7 & 10.6 \\
\hline Pectins $\ldots \ldots \ldots \ldots \ldots \ldots$ (\%) & 0.2 & 0.4 & 0.4 & 0.7 & 0.5 & 0.5 & (c) & 0.5 \\
\hline
\end{tabular}

(a) Determinations on a dry weight basis.

(b) Average of three replications.

(c) Insufficient sample.

The percentage of ash we found in our study was within the range reported by earlier authors. For example, TODD and BRETHERICK (1942) reported that the ash content of bee-collected pollen ranged from 0.91 to $6.36 \%$ with a mean of $2.70 \%$. Also, they found no great difference in ash levels between hand- and beecollected pollens. The higher levels of ash that we found in pollen (3.17\%) compared with that in bee bread (2.76\%) was, however, surprising. One would suspect that bee bread contains higher levels due to the addition of honey. WhITE et al. (1962) and WHITE (1965) found levels of ash in excess of $1 \%$ in honey samples. 
The lipid content of pollen and bee bread in our seven samples ranged from $3.86 \%$ to $6.73 \%$. TODD and BRETHERICK (1942) analyzed 32 plant species, five handcollected and 27 bee-collected, and found a wide range in the ether extract of beecollected pollen $(0.94$ to $14.44 \%$ with a mean of $4.96 \%)$. The highest values were found in dandelion and mustard, and the lowest in birch brush and buckthorn. STANDIFER (1966) determined the lipid constituents of 16 species of beecollected and three species of hand-collected pollen and found the total lipid content ranged from $1.5 \%$ in the heartsease to $18.9 \%$ in dandelion, a mean of $9.2 \%$.

We found starch present in pollen but not in bee bread. However, when $100 \mathrm{mg}$ bee bread or pollen were mixed with concentrations of soluble starch ranging from $10 \mathrm{mg}$ to $100 \mathrm{mg}$ in $20 \mathrm{ml} \mathrm{H}_{2} \mathrm{O}$ (Table 3), starch hydrolysis was rapid. After 1 day, five of 10 tubes incubated with bee bread had hydrolyzed the soluble starch, and all the starch was hydrolyzed after 2 days. The results after 1 day were not conclusive. We added the $100 \mathrm{mg}$ aliquots of bee bread to the tubes without regard to the portion of the pellet used, but we subsequently found that most of the enzymatic activity occurred in the top portion of the pellet containing the honey layer. None of the pollen samples hydrolyzed the starch during 12 days of incubation. Thus the lack of starch in bee bread apparently results from the honey and enzymatic secretions added to the pollen as it is packed by the honey bees. Amylase and invertase are, in fact, secreted by the bee food glands (RINAUDo et al. 1973), but starch has not been found in nectar (WHITE, 1967); so the function of amylase in honey is not clear. WHITE et al. (1962) tested 490 samples of honey and found amylase present in varying amounts in nearly all honeys.

TABLE 3. - Amylase activity (a) in bee-collected pollen and bee bread

\begin{tabular}{|c|c|c|c|c|c|c|c|c|c|c|}
\hline \multirow{3}{*}{$\begin{array}{l}\text { Amount (mg) soluble } \\
\text { starch } / 20 \mathrm{ml} \mathrm{H} \mathrm{H}_{2} \mathrm{O}\end{array}$} & \multicolumn{3}{|c|}{ Bee bread } & \multicolumn{7}{|c|}{ Pollen } \\
\hline & \multicolumn{3}{|c|}{ Day } & \multicolumn{7}{|c|}{ Day } \\
\hline & 0 & 1 & 2 & 0 & 1 & 2 & 5 & 7 & 9 & 12 \\
\hline 10 & - & + & + & - & - & - & - & - & - & - \\
\hline 20 & - & + & + & - & - & - & - & - & - & - \\
\hline 30 & - & - & + & - & - & - & - & - & - & - \\
\hline 40 & - & + & + & _- & - & - & - & - & - & - \\
\hline 50 & - & - & + & - & - & - & - & - & - & - \\
\hline 60 & - & + & + & - & - & - & - & - & - & - \\
\hline 70 & - & - & + & - & - & - & - & - & - & - \\
\hline 80 & - & - & + & - & - & - & - & - & - & - \\
\hline 90 & - & + & + & - & - & - & - & - & - & - \\
\hline 100 & - & - & + & - & - & - & - & - & - & - \\
\hline
\end{tabular}


The concentration of reducing sugars in pollen shown in Table 2 is not a true value for pollen as produced by the plant. Also the content of sugars in pollen from pollen traps is considerably greater than the content in pollen gathered by hand. LUNDEN (1954) reported that bee-collected pollens always contain larger amounts of reducing sugars because of the honey or nectar in the fluid used to cement the grains together. Maltose is the most common reducing disaccharide found in nature as a constituent of the polysaccharides, starch, and glycogen. Sucrose is the only important nonreducing disaccharide.

The higher level of reducing sugar in bee bread therefore probably results from the addition of honey or nectar as the pollen is prepared for storage. The added honey reduces the $p \mathrm{H}$ from 4.8 in pollen to an average of 4.07 in bee bread, which facilitates the growth of some apparently desirable microorganisms (Egorova, 1971).

A considerable percentage of undetermined matter remained after removal of water, ash, lipids, protein, sugars, and starch from pollen. Even after an additional analysis for crude fiber (mean $7.73 \%$ ) and pectins (mean $1.56 \%$ ), there were still some undetermined materials. Some authors have assumed these additional undetermined materials to be pigments, waxes, and resins. However, the percentage reported in this study (mean $9.59 \%$ for pollen) was less than the values reported by ToDD and BRETHERICK (1942). They found a range from 21.65 to $35.87 \%$, with a mean of $28.55 \%$. These authors attributed these high percentages in part to substances called "pollenin", which builds up the extremely resistant exterior pollen membranes. Pollenin contents were determined and found to be $21.9 \%$ in spruce, $20 \%$ in silver pine, and $7.3 \%$ in hazelnut.

In sum, there was no observable nutritional difference between pollen and bee bread fed to caged colonies of bees based on number of larvae reared to pupation. Bee bread and pollen had similar levels of protein, moisture, and lipid. Starch was present in all pollen samples, but absent from bee bread. The levels of reducing and nonreducing sugar, ash, and crude fiber were within the range of experimental error. This information suggests that either pollen or bee bread might be used as a standard in the formulation of our future basal diets.

\section{REFERENCES}

Association of Official Agricultural Chemists. Methods of Analysis. 9th Ed. 1960.

Beutler R. and Opfinger E., 1949. - Pollenernährung und Nosemabefall der Honigbiene. $Z$. vergl. Physiol., 32, 383-421.

Egorova A. I., 1971. - Preservative microflora in stored pollen. Veterinariya (8), 40-41. Translation from Russian.

Hagedorn H. H. and Moeller F. E., 1967. - The rate of pollen consumption by newly emerged honeybees. J. apicult. Res., 6 (3), 159-162.

HAYDAK M. H., 1933. - The value of foods other than pollen in the nutrition of the honeybee. Arch. Bienenkd., 14, 185-219. 
Hugel M. F., 1962. - Etude de quelques constituants du pollen. Ann. Abeille, 5, 97-133.

LeEs R., 1971. - Laboratory Handbook of Methods of Food Analysis. CRC Press, Cleveland, Ohio, $192 \mathrm{pp}$.

Louveaux J., 1963. - Le rôle du pollen dans l'alimentation de la ruche. Ann. Nutr. Aliment, 17 (1), 313-318.

LUNDEN R., 1954. - A short introduction to the literature on pollen chemistry. Svensk kem Tidskr., 66, 201-213.

MAURIzIO A., 1954. - Pollenernährung und Lebensvorgänge bei der Honigbiene (Apis mellifica L.) Landwirtschaftliches Jb. Schweiz., 68 (2), 115-182.

Pain J. and Maugenet J., 1966. - Recherches biochimiques et physiologiques sur le pollen emmagasiné par les abeilles. Ann. Abeille., 9, 209-236.

Rinaudo M. T., Ponzetto C., Vidano C. and Marletto F., 1973. - The origin of honey amylase. Comp. Biochem. Physiol., 46 B, 253-256.

StandifER L. N., 1966. - Some lipid constituents of pollens collected by honeybees. J. apicult. Res., 5, 93-98.

Todd F. E. and Bretherick O., 1942. - The composition of pollens. J. econ. Ent., 35, 312-316.

Vivino E. A. and PALMER L. S., 1944. - Chemical composition and nutritional value of pollen. Arch. Biochem., 4, 129-136.

White J. W., Riethof M. L., Subers M. H. and Kushner 1., 1962. - Composition of American honeys. Tech. Bull. U.S. Dep. Agric., 1261, 124 pp.

White J. W., 1967. - Honey, its composition and properties. pp. 56-64 in Beekeeping in the United States. Handb. U.S. Dep. Agric., 335, 147 pp.

White J. W., 1975. - Honey. Pages 491-530 in Dadant and Sons (eds.). The Hive and the Honey Bee. Dadant and Sons, Hamilton, 111, 740 pp.

\section{ZUSAMMENFASSUNG}

\section{CHEMISCHE ZUSAMMENSETZUNG UND NÄHRWERT VON POLLEN, DER VON BIENEN GESAMMELT ODER GESPEICHERT WURDE}

Wenn frisch gesammelter Pollen und aus Brutwaben freifliegender Völker entnommener, gespeicherter Pollen (Bienenbrot) an gekäfigte Bienenvölkchen verfüttert wurde, zeigte sich kein Unterschied des Nährwertes in bezug auf die Menge der bis zur Verdeckelung aufgezogenen Brut. Bienen, die entweder mit Pollen oder mit Bienenbrot gefüttert wurden, zogen $7,19550 \mathrm{~cm}^{2}$ und $7,04600 \mathrm{~cm}^{2}$ Brutflächen bis zur Verdeckelung auf.

Bienenbrot und Pollen aus sieben geographisch verschiedenen Orten der U.S.A. wurden auf Feuchtigkeitsgehalt, Proteine, reduzierende und nicht reduzierende Zucker, auf Lipide, sulfatierte Asche, Stärke, $p \mathrm{H}$, Pektine und feste Bestandteile untersucht. Der Gehalt an Feuchtigkeit, Proteinen und Lipiden wies in Pollen und Bienenbrot nur geringe Unterschiede auf. In keiner der Bienenbrotproben war Stärke nachzuweisen, aber in allen sieben Pollenproben war Stärke vorhanden (Durchschnittswert $=1,77 \%$ ). Bienenbrot enthielt ausserdem mehr reduzierende Zucker und feste Bestandteile als der Pollen, aber weniger Asche. Die Asche aller Pollenproben betrug zwischen 2,4 \% und 3,4\% des Trockengewichtes. Der höhere Gehalt des Bienenbrotes an reduzierendem Zucker ist vermutlich auf den Honig- oder Nektarzusatz bei der Pollenverarbeitung für die Speicherung zurückzuführen. Der zugesetzte Honig verringerte das $p \mathrm{H}$ von 4,8 im Pollen auf durchschnittlich 4,07 im Bienenbrot. Der Prozentsatz nicht bestimmter Substanzen in Pollen und Bienenbrot betrug durchschnittlich weniger als $10 \%$ des Trockengewichtes. 


\section{RESUMÉ \\ COMPOSITION CHIMIQUE ET VALEUR NUTRITIVE DU POLLEN RÉCOLTÉ PAR LES ABEILLES ET DU POLLEN STOCKÉ DANS LA RUCHE}

Après avoir offert à des nucléi d'abeilles en cagettes du pollen frais et du pollen stocké, extrait de rayons de couvain de colonies volant librement, on n'a noté aucune différence dans la valeur nutritive évaluée d'après le nombre d'abeilles élevées jusqu'au stade de couvain operculé. Les abeilles ayant reçu soit du pollen, soit du pain d'abeilles ont élevé respectivement $7195,50 \mathrm{~cm}^{2}$ et $7046,00 \mathrm{~cm}^{2}$ de larves jusqu'au stade operculé.

On a analysé dans du pain d'abeilles et du pollen provenant de 7 localités différentes des États-Unis la teneur en eau, les protéines, les sucres réducteurs et non-réducteurs, les lipides, les cendres sulfatées, l'amidon, le $p \mathrm{H}$, les pectines et les constituants bruts. Les teneurs en protéine et en eau et les lipides diffèrent peu du pollen au pain d'abeilles. Pourtant, on n'a décelé aucune trace d'amidon dans aucun des échantillons de pain d'abeilles, alors que l'amidon était présent dans les 7 échantillons de pollen (valeur moyenne de $1,77 \%$ ). De plus, le pain d'abeilles contenait de plus fortes teneurs en sucres réducteurs et en constituants bruts, mais des teneurs plus faibles en cendres. Les cendres de tous les échantillons de pollen représentaient de 2,4 à $3,4 \%$ du poids sec. La teneur plus élevée en sucres réducteurs du pain d'abeilles résulte probablement de l'addition de miel ou de nectar au moment où le pollen est préparé à être stocké. Le miel ainsi ajouté abaisse le $p \mathrm{H}$ de 4,8 dans le pollen à 4,07 en moyenne dans le pain d'abeilles. Le pourcentage de substances non déterminées dans le pollen et le pain d'abeilles est en moyenne inférieur à $10 \%$ du poids sec. 